\begin{tabular}{|l|l|l|}
\hline \multicolumn{2}{|c|}{ PublisherInfo } \\
\hline \hline PublisherName & $:$ & BioMed Central \\
\hline \hline PublisherLocation & $:$ & London \\
\hline \hline PublisherImprintName & $:$ & BioMed Central \\
\hline \hline
\end{tabular}

\title{
A potential mechanism for anti-inflammatory effects of PPARs
}

\begin{tabular}{||l|l|l||}
\hline \multicolumn{2}{|c||}{ ArticleInfo } \\
\hline \hline ArticleID & $:$ & 227 \\
\hline \hline ArticleDOI & $:$ & $10.1186 /$ ar-1999-66753 \\
\hline \hline ArticleCitationID & $:$ & 66753 \\
\hline \hline ArticleSequenceNumber & $:$ & 184 \\
\hline \hline ArticleCategory & $:$ & Paper Report \\
\hline ArticleFirstPage & $:$ & 1 \\
\hline \hline ArticleLastPage & $:$ & 1 \\
\hline \hline & & RegistrationDate : 1999-11-26 \\
ArticleHistory & $:$ & OnlineDate $:$ 1999-11-26 \\
\hline \hline ArticleCopyright & $:$ & Current Science Ltd1999 \\
\hline \hline ArticleGrants & $:$ & \\
\hline \hline ArticleContext & $:$ & 130753311 \\
\hline \hline
\end{tabular}


Aff1 Kennedy Institute of Rheumatology, London, UK

\section{Keywords}

Atherosclerosis, IL-6, NF-aB, PPAR, transcription

\section{Context}

Atherosclerosis is characterised by chronic inflammation, the presence of activated macrophages and proinflammatory cytokines, including interleukin-6 (IL-6). The peroxisome proliferator-activated receptors (PPARs) are members of the nuclear hormone receptor family of transcription factors, and have been described as antagonists of proinflammatory cytokine synthesis. Ligands of PPARa inhibit IL-6 expression in atherosclerosis, and in isolated IL-1-stimulated aortic smooth muscle cells. The mechanism of action of PPARs is not known. To examine the molecular mechanism by which PPARs inhibit the production of IL-6.

\section{Significant findings}

Aortic explants from PPARa -/- mice overexpressed IL-6 protein in response to an liposaccaride (LPS) challenge. The knockout mice were also resistant to the inhibitory effects of a PPARa ligand upon IL-6 mRNA expression. In isolated human aortic smooth muscle cells, a PPARa ligand reduced expression of IL-6 mRNA in response to an IL-1 challenge. The IL-6 promoter contains NF-?B and AP-1 binding sites, and was activated by coexpression of the NF-aB component $\mathrm{p} 65$, or the AP-1 component c-jun in transfected COS-1 cells. Either activation was blocked by PPARa coexpression. Reciprocally, activation of an appropriate reporter construct by PPARa was inhibited by $\mathrm{p} 65$ or c-jun coexpression. Chimeric transcription factors were used to demonstrate that inhibition occurs at the level of transcriptional activation rather than DNA binding. Direct interactions between PPARa and p65 or cjun were demonstrated by means of affinity chromatography.

\section{Comments}


This paper is of oblique significance to arthritis. In common with a number of recent papers, it illuminates a potential immunomodulatory function of the PPAR family of transcription factors. The targets described in this paper are the transcription factors $N F-? B$ and $A P-1$, which are frequently required for the expression of proinflammatory genes (such as TNFa). It might be predicted that PPAR ligands will display a broad spectrum of anti-inflammatory properties in cells which express the appropriate receptors, and such compounds may be of interest as anti-inflammatory agents in conditions other than atherosclerosis. It will be important to extend the observations described here to genes other than IL-6, and to systems other than the rather inappropriate COS-1 cell line employed. It is difficult to assess the strength of the physical interactions shown, and conclusions about the precise mechanism of cross-talk should be regarded as tentative.

\title{
Methods
}

ELISAs and northern blots are used to examine IL-6 protein and mRNA expression in aortic explants of wild type and PPARa, knockout mice and isolated human aortic smooth muscle cells. The mechanism of action of PPARa is examined by means of transient transfection and reporter gene assays in COS-1 cells (a monkey kidney fibroblast line). Protein-protein interactions are assessed by means of affinity chromatography using bacterially-expressed and in vitro translated proteins.

\section{Additional information}

\author{
See related report on Huang et al
}

Nature 1999, 400:378-382.

\section{References}

1. Delerive P, De Bosscher K, Besnard S, Vanden Berghe W, Peters JM, Gonzalez FJ, Fruchart J-C, Tedgui A, Haegeman G, Staels B: Peroxisome proliferator-activated receptor alpha negatively regulates the vascular inflammatory gene response by negative cross-talk with transcription factors NF-?B and AP-1. J Biol Chem. 1999, 274: 32048-32054.

This PDF file was created after publication. 